\title{
Basım Sanayi ve Matbaa Sektöründe İş Sağlığı ve Güvenliği Kanununun Getirdiği Yasal Zorunluluklar
}

Semiha YENIDOĞAN, Marmara Üniversitesi, Uygulamalı Bilimler Yüksekokulu, Basım Teknolojileri Bölümü, Doç. Dr., semihayavuz@marmara.edu.tr

Sevil ÇıRAKOĞLU, Bursa Uludağ Üniversitesi, Teknik Bilimler Meslek Yüksekokulu, İs Sağlığı ve Güvenliği Programı, Öğr. Gör., sevilcirakoglu@uludag.edu.tr

ÖZET Basım Endüstrisi tehlikeli kimyasalların kullanıldığı, ağır yüklerin taşınmasını gerektiren, elektrik enerjisinin yoğun olduğu, hareketli silindir ve kesici makinelerin kullanıldığı bir iş kolu olduğundan iş sağlı̆̆l ve güvenliği açısından geniş kapsaml incelenmesi gereken bir sektördür. İnsan sağlığı açısından riskli faaliyetler içeren olumsuz koşullar basım sanayi ve matbaa sektöründe de olması sebebi ile iş sağhlğı ve güvenliğinin de önemini arttırmaktadır.

26.12.2012 tarihli Resmi Gazetede yayınlanan İş Să̆lı̆̆ı ve Güvenliğine İlişkin İş yeri Tehlike Sinıfları Tebliğindeki Ek-1'e göre tehlikeli iş yeri sinıfinda yer almaktadır. Bu durumunda basım sanayi ve matbaa sektöründe iş sağhl̆ğ ve güvenliğgi konusunda geniş bir değerlendirmeyi hak etmekte ve gerekli kilmaktadır.

Bu makalede, basım sanayi ve matbaa sektörünün iş sağlı̆̆ ve güvenliği bakımından bir değerlendirmesi yapılmış ve yasal zorunluluklar incelenmiştir. Öncelikli olarak basım sanayi ve matbaa sektörünün genel özelliklerine kısaca değinilmiş daha sonra, basım sanayi ve matbaa sektöründeki işler ve riskler, iş kazaları ve meslek hastalıkları çeşitli boyutlarıyla ele alınmıştır. Sektör iş sağllğı ve güvenliği boyutuyla değerlendirilmiştir.

Anahtar kelimeler: İ̧s sağhlğı ve güvenliği, Basım endüstrisi, Basım endüstrisi ve matbaa sektöründe iş sağlı̆̆l ve güvenliği.

\section{Statutory Obligations Incurred by Occupational Health and Safety Law in Printing Industry and Printing Sector}

\footnotetext{
ABSTRACT Printing industry is a sector requiring extensive examination in terms of occupational health and safety due to being a line of work having hazardous chemical used therein, requiring transport of heavy loads, having intensive electrical energy, and having movable cylinder and sharp objects use. The fact that negative conditions containing risky activities in terms of human health are present in the printing industry and press sector increases the importance of occupational health and safety. According to Annex-1 in the Notification of Workplace Hazard Classes Relating to Occupational Health and Safety published in the Official Gazette dated 26.12.2012, it is within the class of hazardous workplace. Thus, occupational health and safety in the printing industry and press sector worth and required an extensive evaluation.

In this article, evaluation of printing industry and press sector in terms of occupational health and safety was carried out and statutory obligation was examined. Firstly, general features of the printing industry and press sector were briefly mentioned, afterwards works and risks, occupational accidents and occupational diseases in the printing industry and press sector were handled with various dimensions thereof. The sector was evaluated with its dimension of occupational health and safety thereof.
} 
Keywords: Occupational health and safety, Printing industry, Occupational Health and Safety in industry and printing sector.

\section{Giriş}

Matbaacılık, metin ve görsellerin genellikle kâğıt gibi baskı altı malzemeleri üzerine basılarak çoğaltılma işidir. Matbaa, ağaç oyma tekniği kullanarak, ilk olarak M.S. 593'te Çin'de kurulmuş, 18. yy' da (1727) Türkiye'ye gelmiştir. Günümüzde matbaalarda kitap, gazete, dergi, kartvizit gibi son kullanıcıya yönelik ürünlerin yanı sıra seri üretimde kullanılmak üzere ambalajlar ve paketleme malzemeleri de üretilmektedir. Ülkemizde matbaacılık sektörü teknoloji olarak hemen hemen dünya ile aynı seviyededir (Fişek \& Taşyürek, 2019). Teknolojinin gelişmesi matbaacılık mesleğini de etkilemiş ve üretimde kullanılan makineler bilgisayar kontrollü hale gelmiştir.

Kısaca matbaacılık denilen karmaşık süreç, farklı teknolojilere ait çok sayıda işlemden oluşur. Genel olarak bir matbaanın üretim bölümleri temelde baskı öncesi, baskı ve baskı sonrası olarak tanımlanabilir. Bu bölümleri üretim planlama, kalite kontrol, satış-pazarlama gibi bölümler destekler (Marmara Üniversitesi, 2019).

Baskı öncesi: Öncelikle basılacak işin tasarımı yapılır. Bu aşamada metinlerin, görsel ve fotoğrafların bilgisayar ortamına aktarılması gerekir. Bilgisayar ortamına aktarılan metin ve görsel öğeler mizanpaj yazılımında bir araya getirilerek baskıya uygun tasarımlar oluşturulur. Bilgisayar yardımıyla yapılan bu işleme masaüstü yayıncılık da denir. Sonrasında, yapılan çalışmanın film çıkışları alınır. Film, baskı için kullanılan kalıbı oluşturmak için kullanılır. Filmden sonra ürünün kontrolü için prova baskısı alınmaktadır. Filmden alınan provaya analog prova denmektedir. Analog provanın dışında baskıyı taklit eden son kontroller için yazıcılarla dijital prova da alınmaktadır.

Baskı: Film çıkışları alındıktan sonra alüminyum plakalar (baskı kalıbı) üzerine tasarımın görüntüsü çıkarılır. Kalıp çekme denilen bu işlem iki aşamada gerçekleşir: film kullanarak kontakt baskı yani pozlandırma ve banyo işlemidir. Günümüzde tasarımlar bilgisayardan direk kalıba alınabilmekte, CTP adıyla anılan bu sistem ile film ve montaj işlemlerini ortadan kaldırmaktadır. Kalıp çekildikten sonra baskı işlemi gerçekleştirilir (Matbaa Bilgi Kütüphanesi, 2019).

Sektörde tipo ve ofset baskıdan günümüzde yaygın olarak kullanılan baskı çeşitleri olarak, tifdruk ve flekso baskı (ambalaj özellikle foto polimer yüzeylerin baskısı), serigrafi baskı (kâğıt, seramik, tekstil vb. yüzeyler), hologram ve tampon baskı çeşitleri de kullanılan baskı tekniklerindendir (Fişek \& Taşyürek, 2019).

Baskı sonrası: Baskı sonrasında selefon, lak gibi malzemelerle yüzey kaplama (laminasyon) işlemleri uygulanmaktadır. Mücellithane makinaları kullanılarak da çok sayfalı ürünlerde katlama, harmanlama, iplik dikiş, tel dikiş gibi işlemler, kitap ve dergiler için kapak takarak ciltleme gibi, ambalajlar için kalıplı kesim gibi işlemler gerçekleştirilmektedir (Matbaa Bilgi Kütüphanesi, 2019). 


\section{Basım Sanayi ve Matbaa Sektörü Riskleri ve Yasal Düzenlemeleri}

1492 yılında Gutenberg tarafından icadından sonra yavaş yavaş gelişen matbaa teknolojisi 20 yy ofset tekniği yaygın olarak kullanılmaya başlamış olmakla birlikte 21 yy girerken baskı makineleri de dijital sisteme geçmiş, eski tehlike ve risklerin yerini yenileri almıştır.

6331 sayılı müstakil bir iş sağlığı ve güvenliği yasası çıkarılması iş kazalarının ve meslek hastalıklarının önle bilmesi için ülkemizde de bu yasayla birlikte bir iş sağlığı ve güvenliği kültürünün oluşmasının üzerinde durulmuştur. İş güvenliği kültürü olumlu anlamda farkındalık yaratmak için eğitimin her sürecine, seviyesine iş sağlığı ve güvenliği eğitimlerini yerleştirilmelidir.

Çalışma ve Sosyal Güvenlik Bakanlığı: İşverenlerin, iş güvenliği uzmanlarının ve işyeri hekimlerinin risk değerlendirme sürecini kolaylaştırmak ve yol göstermek ayrıca 6331 sayılı İş Sağlığı ve Güvenliği kanunun getirdiği yükümlülüklere uyum sağlamaları adına çeşitli sektörlere yönelik örnek niteliğinde risk değerlendirme rehberleri yayımlamıştır.

Basım sanayi ve matbaa sektörünün kontrol listesinde yer alan risklerin ana başlıkları : Genel \& Tertip - Düzen ve Hijyen, Elektrik, Makineler, El Aletleri ve Yardımcı Aparatlar, Kimyasallar, Yangın ve Acil Durumlar, Gürültü, Radyasyon, Elle Taşıma, Ergonomi, Psikososyal Etkenler, Kazalar ve Hastalıklar, Eğitim ve Bilgilendirme başlıklarını içermektedir (bilgit.com, 2019).

\section{Bu riskler genel olarak alt başlıkları ise aşağıda verilmiştir.}

- Matbaacılık iş kolunda kullanılan UV-mürekkeplerin solunmasıyla çalışanlarda astım görülme riski artar (Fişek \& Taşyürek, 2019).

- Depolama ve kağıt taşıma sırasında: Matbaalarda malzeme depolama, kağıt taşıma ve istifleme iş sağlı̆̆ı ve güvenliği açısından önemlidir.

- Kağıt kesme sırasında: Giyotinler, kesici bıçağın dikey doğrultuda hareket ederek kağıdı kesmeye yarayan makinalardır. Giyotin makinalarının en büyük riskleri el sıkıştırmaları veya makineye yerleştirilen kağıtlarla birlikte metal parçaların olması makinanın sıkışması, bıçağın kırılması ve parça fırlaması gibi durumlarla karşılaşılabilmektedir.

- Tel zımbalama işlemi sırasında: Matbaalarda basılan bazı dokümanlar) fatura, makbuz, sayfa sayısı az olan kitaplar) telli zımbalarla birleştirilir. Bu makinelerde çalışacak personellerin el sıkışmalarına dikkat etmeleri gerekmektedir.

- Ciltleme işlemi sırasında: Sayfa sayısı fazla olan kitapların ciltlenmesinde tutkallı veya iplikli dikiş tekniği kullanılmaktadır. Tutkal gibi kimyasallarla çalışıldığından gerekli koruyucu malzemeler kullandırılmalıdır. Sürekli tekrarlanan işler olduğundan devamlı ayakta durmaktan kaynaklanan rahatsızlıklar, oturarak çalışmada ise sürekli eğilip doğrulmak, sürekli ileriye uzanmak ve benzeri hareketlerden kaynaklanan ergonomik sorunlar ortaya çıkabilir.

- Ambalaj bitmiş işlerin müşteriye teslim edilecek şekilde ambalajlanması sırasında ergonomi yine ön plandadır.

- Pikaj ve montaj işleri bilgisayar teknolojisi sayesinde önemli ölçüde ihtiyaç dışı olmuştur. Bu işlerde en önemli tehlike olarak yine ergonomi görülmektedir. Bunun dışında gözler aşırı dikkatli işler nedeniyle yorulmakta ve stres ortaya çıkabilmektedir.

- Kalıp pozlandırma (çinko hazırlama) sırasında: Montaj safhası tamamlanmış işler kalıp hazırlanmak üzere çinko makinesine verilir. Günümüzde Ctp tekniği bu işleri azaltmış 
olmakla birlikte çinko kalıplarını kullanan matbaa oldukça fazladır. Kalıp hazırlama işlerinde en önemli tehlike kullanılan kimyasallardır (Erdim, Türkman, \& Atalar, 2010, s. 93).

- Makinaların temizlenmesinde : Bask1 makinelerinin her bask1 sürecinden sonra temizlenmesi ve günlük, aylık, yıllık periyodik bakım planlarının oluşturularak bakımlarının aksatılmaması gerekmektedir. Temizleme esnasında solvent bazlı kimyasallar kullanılmaktadır. Solventlerle temas edilmesi ve bu solventlerin deri yoluyla emilmesi nedeniyle çalışanlarda alerjik egzama hastalığı görülmesi mümkündür. Solvent buharının solunması ile çalışanlarda baş ağrısı ve bulantı görülebilir ve aynı nedenden merkezi sinir sistemi üzerinde geçici etki oluşabilir.

- Basım işlemi sırasında veya sonrasında temizlik için kullanılan biositler, formaldehit, diklorometan, NVP gibi toksik maddeler solunması veya deri ile teması nedeniyle bu maddelerle yoğun olarak çalışan işçilerde kanser hastalığının görülme riski artar (Fişek \& Taşyürek, 2019).

- Perforaj ve Pilyaj: Baskı ofset makinelerinde yapılmış olsa dahi işlerin numaralandırılması, perforaj veya pilyaj işlemleri ve ambalaj kutularındaki kesme işlemleri, tipo makinelerinde veya rotatif makinelerde yapılır. Bu işlemlerdeki tehlikeler el sıkışması, ağır cisim kaldırma, ayağa ağır cisim düşmesi ve gürültü, titreşim gibi fiziksel tehlikelerdir (Erdim, Türkman, \& Atalar, 2010, s. 86).

- Baskı öncesi ya da baskı sonrası bekletilmiş kimyasalların bozulması, burada bakteri üremesi ve bu kimyasalın buharının solunmasıyla ya da deriye temas etmesiyle maruz kalınan mikroorganizmalar çalışanda nemli ateş basması ve Lejyoner Hastalığına neden olabilir. (Lejyoner Hastalığı suda bulunan çeşitli bakterilerin neden olduğu bir hastalıktır. Bu bakteriler akciğere yerleşerek zatürreye yol açar) (Fişek \& Taşyürek, 2019).

- Matbaalarda en çok tüketilen maddeler arasında "Speragum" ve çoğu yerde "Fikser" olarak adlandırılan kalıp temizleme sütü bulunmaktadır. Bu ikili ucuz olmasının yanı sıra, aslında matbaacıya en çok zarar veren kimyasallardır. Uçucular ve bazı kimyasal sentetik maddeler, özellikle çocuklarda koklama ve solunum yolu ile uyuşturucuya alışma nedeni olabilmektedir.

- Matbaalarda kullanılan tehlikeli maddeler, kimyasallar: Parlayıcılar, patlayıcılar, Yakıtlar, yağlar, Yağlama kapları, Tüpler, Boyalar/tinerler/ çözücüler ve buharları, Temizlik için kullanılan sıvılar, Yapıştırıcılar, Asitler, bazlar, tuzlar, Tozlar, Ofis malzemeleri, Makinalardan kaynaklanan egzoz gazları, bazı maddeler tehlikeli kategorisine girmekle beraber, riskinin düşük olması nedeniyle pratik olarak zararsız olarak kabul edilebilir (Erdim, Türkman, \& Atalar, 2010, s. 46). Matbaalarda toz miktarı az olmakla birlikte çeşitli açılardan önemlidir. Tozlar genellikle kağıt harmanlama ve aktarma sırasında ortaya çıar ve insan sağlığı üzerinde olumsuz etki yapabilirler (İzmir Alternatif OSGB, 2019).

- Matbaalarda, gerekli önlemler alınmadığı takdirde çalışanlar ses ve gürültüden kaynaklanan olumsuz etkilere maruz kalabilmektedir. Gürültü genel olarak istenmeyen rahatsız edici ses olarak tanımlanır. Endüstrideki gürültü ise iş yerlerinde çalışanların işitme sağlı̆̆ını ve algılamasını olumsuz yönde etkileyen, fizyolojik ve psikolojik etkiler bırakan ve iş verimini olumsuz yönde etkileyen sesler olarak tanımlanmaktadır. Gürültünün insan sağlığı üzerine başlıca etkileri; işitme hasarları şeklinde görülen fiziksel etkiler, vücut aktivitesinde görülen fizyolojik etkiler, rahatsızlıklar, sinirlilik gibi psikolojik etkiler ve iş veriminin azalması, işitilen seslerin anlaşılamaması gibi etkilerdir. 
- Matbaalarda çalışan işçilerin maruz kalabilecekleri bir diğer sağlık sorunu aletlerin kullanımı sırasında maruz kalınan titreşim sorunudur. Mekanik titreşim insanlarda pek çok organda sorun oluşturabilmektedir. El-kol titreşimi, damar, kemik, eklem, sinir ve kas bozukluklarına; bütün vücut titreşimi ise, mekanik titreşim olarak, vücudun tümüne aktarıldığında, işçilerin sağlık ve güvenliği için risk oluşturan, özellikle de, bel bölgesinde rahatsızlık ve omurgada travmaya yol açan titreşimi olarak tanımlanmaktadır.

- Matbaalarda sıklıkla karşılaşılan bir diğer sorun, iskelet sistemi rahatsızlıklarıdır.

- Psikolojik stres ve aşırı yüklenmeler, çalışanlarda uyku bozuklukları, tükenme sendromları, ve depresyona neden olabilir. İş stresine bağlı olarak kalp-damar sistemi hastalıklarında, özellikle koroner damar hastalıkları ve hipertansiyonda artış olduğu bildirilmiştir. Hayatı tehdit eden ya da ölümle sonuçlanan büyük kazalar ve faciaların, çalışanlarda ağır psikolojik bozukluklara neden olduğu görülmüştür. İş stresi çoğu zaman mesleki yetersizliğe, diğer bir ifade ile psikolojik sakatlığa yol açmaktadır. Bu da iş veriminin azalması ve ekonomik kayba neden olmaktadır (Erdim, Türkman, \& Atalar, 2010, s. 63).

- Matbaacılık işkolunda en sık karşılaşılan yangın türü baskı için kullanılmak üzere depolanan kağıt, karton, plastik ve benzeri yanıcı katı maddelerin tutuşmasıyla ortaya çıkan A sınıfı yangınlardır. Bununla birlikte yine depolama alanlarında bol miktarda bulunabilen mürekkep, alkol, yağlar ve solventler gibi yanıcı sıvıların yanmasıyla B sınıfı yangınlar da bu işkolunda görülebilir. Elektriğin yoğun olarak kullanıldığı bir işkolu olduğundan elektrik kaçağı nedeniyle C sınıfı yangınlar da matbaacılıkta karşılaşılabilecek iş kazalarındandır (Fişek \& Taşyürek, 2019).

Basım sanayi ve matbaa sektöründe riskler genelde yukarıda bahsedildiği şekildedir.

Bu riskleri azaltmak ve önlemek için; 6331 sayılı Kanunun "işverenin genel yükümlülüğü" başlıklı 4 üncü maddesi birinci fıkrasının (c) bendi uyarınca işverenler işyerinde risk değerlendirmesi yapmak veya yaptırmak ile yükümlüdür. Yükümlülüğün ne şekilde yerine getirileceği ile ilgili hususlar ise 29/12/2012 tarih ve 28512 sayılı Resmi Gazete'de yayımlanan İş Sağlığ 1 ve Güvenliği Risk Değerlendirmesi Yönetmeliğinde belirtilmektedir.

29.12.2012 tarihli İş Sağlığ1 ve Güvenliği Risk Değerlendirmesi Yönetmeliğine göre, risk değerlendirmesi; tüm iş yerleri için tasarım veya kuruluş aşamasından başlamak üzere tehlikeleri tanımlama, riskleri belirleme ve analiz etme, risk kontrol tedbirlerinin kararlaştırılması, dokümantasyon, yapılan çalışmaların güncellenmesi ve gerektiğinde yenileme aşamaları izlenerek gerçekleştirilir. Çalışanların risk değerlendirmesi çalışması yapılırken ihtiyaç duyulan her aşamada sürece katılarak görüşlerinin alınması sağlanır. Yapılmış olan risk değerlendirmesi; tehlike sınıfına göre çok tehlikeli, tehlikeli ve az tehlikeli işyerlerinde sırasıyla en geç iki, dört ve altı yılda bir yenilenir (resmigazete.gov.tr). Bu çalışmalar yapılırken ülkedeki ve dünyadaki gelişmelerden haberdar, her konumdaki çalışan ile çalışanlarla ile görüş alışverişinde bulunarak bir sistem anlayışı içerisinde benimsenmiş bir iş güvenliği kültürü oluşturmak gereklidir.

15.05.2013 Resmi Gazete Tarihli Çalışanların İş Sağlığı ve Güvenliği Eğitimlerinin Usul Ve Esasları Hakkında Yönetmeliğine göre çalışanlara iş sağlı̆̆ı ve güvenliği eğitimleri işveren, çalışan fiilen çalışmaya başlamadan önce, çalışanın yapacağ iş ve işyerine özgü riskler ile korunma tedbirlerini içeren konularda öncelikli olarak eğitilmesini sağlar. Çalışma yeri veya iş değişikliği, iş ekipmanının değişmesi, yeni teknoloji uygulanması gibi durumlar nedeniyle ortaya çıkacak risklerle ilgili eğitimler ayrıca verilir. Değişen ve ortaya çıkan yeni riskler de dikkate alınarak düzenli aralıklarla tekrarlanır. Eğitimler basım sanayi ve matbaa 
sektöründe işyeri tehlike sınıfına göre, çok tehlikeli sınıfta yer alan işyerlerinde yılda en az 1 defa, tehlikeli sınıfta yer alan işyerlerinde 2 yılda en az 1 defa, az tehlikeli sınıfta yer alan işyerlerinde 3 yılda en az 1 defa düzenli aralıklarla tekrarlanmalıdır. Verilecek eğitimlerin süresi ise çok tehlikeli işyerleri için en az 16 saat, tehlikeli işyerleri için en az 12 saat, az tehlikeli işyerleri için en az 8 saat olmalıdır. Eğitim süresi bir bütün olması esas olmakla birlikte 4 saat ve katları şeklinde de olabilir.

12.08.2013 Resmi Gazete Tarihli Kimyasal Maddelerle Çalışmalarda Sağlık ve Güvenlik Önlemleri Hakkında Yönetmeliğe göre: Tehlikeli kimyasal maddelerle çalışmalar, en az sayıda çalışan ile yapılır. Çalışanların maruz kalacakları madde miktarlarının ve maruziyet sürelerinin mümkün olan en az düzeyde olması sağlanır. İşyerinde kullanılması gereken kimyasal madde miktarı en az düzeyde tutulur. İşyeri bina ve eklentileri her zaman düzenli ve temiz tutulur. Çalışanların kişisel temizlikleri için uygun ve yeterli şartlar sağlanır. Tehlikeli kimyasal maddelerin, atık ve artıkların işyerinde en uygun şekilde işlenmesi, kullanılması, taşınması ve depolanması için gerekli düzenlemeler yapılır. Tehlikeli kimyasal madde yerine çalışanların sağlık ve güvenliği yönünden tehlikesiz veya daha az tehlikeli olan kimyasal madde kullanılır (resmigazete.gov.tr). “Tüm Kimyasallar Tehlikelidir!” ancak doğabilecek tehlikeler ve zehirlenmeler, kimyasalların doğru ve kullanım şartlarına uygun olarak kullanılmalarıyla önlenebilir (İzmir Alternatif OSGB, 2019).

18.06.2013 Resmi Gazete Tarihli İşyerlerinde Acil Durumlar Hakkında Yönetmeliğe göre: İşyerinde meydana gelebilecek acil durumlar şu hususlar dikkate alınarak belirlenir: risk değerlendirmesi sonuçları, yangın, tehlikeli kimyasal maddelerden kaynaklanan yayılım ve patlama ihtimali, ilk yardım ve tahliye gerektirecek olaylar, doğal afetlerin meydana gelme ihtimali ve sabotaj ihtimalidir. Hazırlanan acil durum planının uygulama adımlarının düzenli olarak takip edilebilmesi ve uygulanabilirliğinden emin olmak için işyerlerinde yılda en az 1 defa olmak üzere tatbikat yapılır, denetlenir ve gözden geçirilerek gerekli düzeltici ve önleyici faaliyetler yapılır.

Resmi Gazete Tarihli 02.07.2013 Kişisel Koruyucu Donanımların İşyerlerinde Kullanılması Hakkında Yönetmeliğine göre: İşveren, toplu korunma tedbirlerine, kişisel korunma tedbirlerine göre öncelik verir. Kişisel koruyucu donanım, risklerin, toplu korunmayı sağlayacak teknik önlemlerle veya iş organizasyonu ve çalışma yöntemleriyle önlenemediği, tam olarak sınırlandırılamadığı durumlarda kullanılır. Kişisel koruyucu donanımlar, işveren tarafından ücretsiz verilir, imalatçı tarafından sağlanacak kullanım kılavuzuna uygun olarak bakım, onarım ve periyodik kontrolleri yapılır, ihtiyaç duyulan parçaları değiştirilir, hijyenik şartlarda muhafaza edilir ve kullanıma hazır bulundurulur. İşveren, kişisel koruyucu donanımları hangi risklere karşı kullanacağı konusunda çalışanı bilgilendirir. İşveren, kişisel koruyucu donanımların kullanımı konusunda uygulamalı olarak eğitim verilmesini sağlar. Kişisel koruyucu donanımlar, istisnai ve özel koşullar hariç, sadece amacına uygun olarak kullanilır.

11.09.2013 Resmi Gazete Tarihli Sağl1k ve Güvenlik İşaretleri Yönetmeliğine göre: İşveren, işyerinde gerçekleştirilen risk değerlendirmesi sonuçlarına göre; işyerindeki risklerin ortadan kaldırılamadığı veya toplu korumaya yönelik teknikler veya işin organizasyonunda kullanılan önlem, yöntem veya süreçlerle yeterince azaltılamadığı durumlarda, sağlık ve güvenlik işaretlerini bulundurur ve uygun yerlerde kullanılmasını sağlar. 
İşveren, işyerinde kullanılan sağlık ve güvenlik işaretleri hakkında çalışanları veya temsilcilerini bilgilendirir, işaretlerin anlamları ve bu işaretlerin gerektirdiği davranış biçimleri hakkında, çalışanların eğitim almasını sağlar.

\section{Basım Sanayi ve Matbaa Sektörü İş Kazaları ve Meslek Hastalıkları}

İş kazası ve meslek hastalığı tanımı, çeşitli kuruluşlarca farklı şekillerde yapılmaktadır. Bu farklılıkları oluşturan iki temel neden vardır. Bunlardan birincisi, bu tanımın yapılış amacıdır ki, daha çok sigorta ve ceza süreçlerini tanımlayan hukuksal gereksinimlerdir. Bu durama göre:

İş kazası: Sigortalının iş yerinde bulunduğu sırada; işveren tarafından yürütülmekte olan iş nedeniyle veya görevi nedeniyle, sigortalı kendi adına ve hesabına bağımsız çalışıyorsa yürütmekte olduğu iş veya çalışma konusu nedeniyle işyeri dışında; bir işverene bağlı olarak çalışan sigortalının, görevli olarak işyeri dışında başka bir yere gönderilmesi nedeniyle asıl işini yapmaksızın geçen zamanlarda; emziren kadın sigortalının, çocuğuna süt vermek için ayrılan zamanlarda; sigortalıların, işverence sağlanan bir taşıtla işin yapıldı̆̆ yere gidiş gelişi sırasında meydana gelen ve sigortalıyı hemen veya sonradan bedenen yada ruhen özüre uğratan olaydır (T.C. Resmî Gazete, 5510 Sosyal Sigortalar ve Genel Sağlık Sigortası Kanunu,, 2019, s. Madde 13) .

İş kazası: İşyerinde veya işin yürütümü nedeniyle meydana gelen, ölüme sebebiyet veren veya vücut bütünlügüüü ruhen ya da bedenen engelli hâle getiren olayı (T.C. Cumhurbaşkanlığı Resmi Gazete, 6331 İş Sağlığı ve Güvenliği Kanunu, 2019, s. Madde 3),

Meslek hastalığı: Sigortalının çalıştığı veya yaptığı işin niteliğinden dolayı tekrarlanan bir sebeple veya işin yürütüm şartları yüzünden uğradığı geçici veya sürekli hastalık, bedensel veya ruhsal engellilik halleridir. Sigortalının çalıştığı işten dolayı meslek hastalığına tutulduğunun; Kurumca yetkilendirilen sağlık hizmet sunucuları tarafından usulüne uygun olarak düzenlenen sağlık kurulu raporu ve dayanağı tıbbî belgelerin incelenmesi, Kurumca gerekli görüldügü hallerde, işyerindeki çalışma şartlarını ve buna bağlı tıbbî sonuçlarını ortaya koyan denetim raporları ve gerekli diğer belgelerin incelenmesi, sonucu Kurum Sağlık Kurulu tarafından tespit edilmesi zorunludur (T.C. Resmî Gazete, 5510 Sosyal Sigortalar ve Genel Sağlık Sigortası Kanunu,, 2019, s. Madde 14).

Meslek hastalığı: Mesleki risklere maruziyet sonucu ortaya çıkan hastalığı (T.C. Cumhurbaşkanlığı Resmi Gazete, 6331 İş Sağlığı ve Güvenliği Kanunu, 2019, s. Madde 3),

Tablo 1: 5510 Sayılı Kanunun 4-1/A Maddesi Kapsamında Kayıtlı Medyanın Basılması Çoğaltılması ve Tüm Sektörlerin İş Kazası/Meslek Hastalığı Geçiren Sigortalı Sayıları

\begin{tabular}{|c|c|c|c|c|c|c|}
\hline Yıllar & \multicolumn{2}{|c|}{$\begin{array}{c}\text { Kayıtlı Medyanın Basılması } \\
\text { Ve Çoğaltılması İş Kaza } \\
\text { Sayısı }\end{array}$} & $\begin{array}{c}\text { Tüm } \\
\text { Sektörler } \\
\text { Toplam İş } \\
\text { Kaza Sayısı }\end{array}$ & $\begin{array}{c}\text { Kayıtlı Medyanın } \\
\text { Basılması Ve } \\
\text { Çoğaltılması } \\
\text { Meslek } \\
\text { Erkek }\end{array}$ & $\begin{array}{c}\text { Kadın } \\
\text { Hastalığı Sayısı }\end{array}$ & $\begin{array}{c}\text { Tüm Sektörler } \\
\text { Toplam } \\
\text { Meslek } \\
\text { Hastalığı } \\
\text { Sayısı }\end{array}$ \\
\hline 2016 & 833 & 62 & 895 & 286.068 & 3 & 597 \\
\hline 2015 & 853 & 34 & 887 & 241.547 & 0 & 510 \\
\hline 2014 & 760 & 44 & 804 & 221.366 & 0 & 494 \\
\hline 2013 & 675 & 46 & 721 & 191.389 & 0 & 351 \\
\hline
\end{tabular}




\begin{tabular}{|c|c|c|c|c|c|c|}
\hline 2012 & 256 & 10 & 266 & 74.871 & 0 & 395 \\
\hline 2011 & 287 & 18 & 305 & 69.227 & 3 & 697 \\
\hline 2010 & 259 & 18 & 277 & 62.903 & 10 & 533 \\
\hline 2009 & 248 & 12 & 260 & 64.316 & 1 & 429 \\
\hline 2008 & 214 & 9 & 223 & 72.963 & 2 & 539 \\
\hline 2007 & 307 & 15 & 322 & 80.602 & 2 & 1.208 \\
\hline
\end{tabular}

Kaynak: SGK İstatistik Yillıkları, 2007-2016, https://tuisag.com/yillik-is-kazalari-istatistikleri/ (Erişim Tarihi:05.04.2019)

Tablo-1' de görüldüğü üzere SGK istatistiklerinin 2007-2016 tarihleri arasındaki tüm sektörlere oranla basım sanayi ve matbaa sektöründe, kayıtlı medyanın basılması ve çoğaltılması iş yeri sınıfında olan iş kazası ve meslek hastalıkları oranı düşük ama hiç yokta değildir. Tablo-2' de İş yeri Tehlike Sınıfı Dağılımına bakıldığında; Kağıt ve kağıt ürünlerinin imalatı, Kimyasalların ve kimyasal ürünlerin imalatı, Başka yerde sınıflandırılmamış makine ve ekipman imalatı, Diğer imalatlar, Toptan ticaret iş sahalarının altından da basım sanayi ve matbaa sektörüne ait işler bulunmaktadır. Ülkemizde iş sağlığı ve güvenliği istatistiklerine ulaşabildiğimiz tek kaynak SGK istatistikleridir. Sosyal Güvenlik Kurumu tarafından yayımlanan yıllık istatistikler incelendiğinde: 2013 yılında Türkiye'de bildirimi yapılan 191.389 iş kazası ve kurum sağlık kurulu tarafından onaylanan 351 meslek hastalığı vakası meydana gelmiş ve iş kazaları sonucunda toplam 1.360 kişi hayatını kaybetmiştir. Ölümle sonuçlanan meslek hastalığı vakası bulunmamaktadır. Bu rakamlara göre, Türkiye'de günde; yaklaşık 524 sigortalı iş kazası geçirmekte, 4 kişi iş kazası sonucu hayatını kaybetmekte ve 5 kişi iş kazası sonucu iş göremez hale gelmektedir. Özellikle bu yıldan sonra iş kazaları istatistiklerinde artış gözükmesi, 6331 sayılı İş Sağlığı ve Güvenliği Kanunu sonrası raporlama

sistemindeki değişiklik ve raporlamanın daha aktif olarak kullanılması, iş güvenliği uzmanlarının kanunla devreye girmesi gibi etkenler bulunmaktadır.

2009 yılına göre 2013 yılında işyeri sayısında \% 32, çalışan sayısında ise \% 38'lik bir artış meydana gelmiş yani işgücü piyasasında büyüme sağlanmıştır. 2009 yılına göre 2012 yılında; yüz binde iş kazası oranında \% 12, ölümlü iş kazası oranında \% 52 azalma izlenmiştir. İş kazası ve meslek hastalığı sonucu yüz bin çalışanda sürekli iş göremezlik oranı ise 2009 yılına göre 2012 yılında \% 11,5 oranında azalmıştır. 2009 yılına göre 2013 yılında meslek hastalıkları sayısında \%14 düşüş görülmüştür.

İş kazaları ve ölüm hızlarına bakıldığında en yüksek dört sektör ön sıralardadır. Bunlar; Metal/Makine sektörü, Madencilik sektörü, İnşaat sektörü ve Kara taşımacılı̆̆ı sektörleridir. $\mathrm{Bu}$ sektörlere bakıldığından basım sanayi sektörü iş kazalarında son sıralarda yer almaktadır.

İş kazaları kadar, ülkemizde meslek hastalıkları da önemli bir sorundur. Meslek hastalıkları konusunda ne yazık ki istatistiki bilgiler de yetersizdir. Bu konunun ayrica incelenmesi ve tartışılması gerekmektedir. Basım sanayi ve matbaa sektöründe 2012 yılından sonra meslek hastalığı bildirimi 2016 yılına kadar yapılmamıştır. 2016 yılında Kayıtlı medyanın basılması ve çoğaltılması sektöründe gazetecilik basımı ve diğer matbaacılık iş kollarında meslek hastalığı bildirimi yapılmıştır. 2016 yılında Kağıt ve kağıt ürünlerinin imalatı ve Kayıtlı Medyanın Basılması Çoğaltılması İş Kazası/Meslek Hastalığı Geçiren Sigortalı Sayıları 
detaylı olarak Tablo'2 de gösterilmektedir. Bu rakamların yanı sıra SGK istatistiklerine yansımayan, meslek hastalıkları sonucu kayıplar da ayrıca dikkate alınmalıdır.

Tablo 2: 5510 Sayılı Kanunun 4-1/A Maddesi Kapsamında Kağıt ve kağıt ürünlerinin imalatı ve Kayıtlı Medyanın Basılması Çoğaltılması İş Kazası/Meslek Hastalığı Geçiren Sigortalı Sayıları 2016 yılı Basım Sanayi Sektörü İş Kazası ve Meslek Hastalığı Sayıları

\begin{tabular}{|c|c|c|c|c|c|c|c|c|}
\hline & & & \multicolumn{3}{|c|}{$\begin{array}{l}\text { İş Kazası Geçiren } \\
\text { Sigortalı Sayıları }\end{array}$} & \multicolumn{3}{|c|}{$\begin{array}{r}\text { Meslek hastalığına } \\
\text { tutulan sigortalı sayısı }\end{array}$} \\
\hline & & & Erkek & Kadın & Toplam & Erkek & Kadin & Toplam \\
\hline \multicolumn{3}{|c|}{ 17-Kağıt ve kağıt ürünlerinin imalatı } & 2.361 & 182 & 2.543 & 0 & 0 & 0 \\
\hline \multirow{7}{*}{$\begin{array}{l}\text { 17-Kağıt ve } \\
\text { kağıt } \\
\text { ürünlerinin } \\
\text { imalatı }\end{array}$} & \multirow{2}{*}{$\begin{array}{l}\text { 1-Kağıt } \\
\text { hamuru. } \\
\text { kağıt ve } \\
\text { mukavva } \\
\text { imalatı }\end{array}$} & 1-Kağıt hamuru imalatı & 222 & 3 & 225 & 0 & 0 & 0 \\
\hline & & 2-Kağıt ve mukavva imalat & 411 & 19 & 430 & 0 & 0 & 0 \\
\hline & \multirow[t]{5}{*}{$\begin{array}{l}\text { 2-Kağıt ve } \\
\text { mukavva } \\
\text { ürünleri } \\
\text { imalatı }\end{array}$} & $\begin{array}{l}\text { 1-Oluklu kağıt ve oluklu } \\
\text { mukavva imalatı ile kağıt ve } \\
\text { mukavvadan yapılan ambalaj } \\
\text { kutuları imalatı }\end{array}$ & 981 & 67 & 1.048 & 0 & 0 & 0 \\
\hline & & $\begin{array}{l}\text { 2-Kağıttan yapılan ev eşyası. } \\
\text { sıhhi ve tuvalet malzemeleri } \\
\text { imalatı }\end{array}$ & 580 & 82 & 662 & 0 & 0 & 0 \\
\hline & & $\begin{array}{l}\text { 3-Kağıt kırtasiye ürünleri } \\
\text { imalatı }\end{array}$ & 47 & 6 & 53 & 0 & 0 & 0 \\
\hline & & 4-Duvar kağıdı imalatı & 3 & 0 & 3 & 0 & 0 & 0 \\
\hline & & $\begin{array}{l}\text { 9-Kağıt ve mukavvadan diğer } \\
\text { ürünlerin imalatı }\end{array}$ & 117 & 5 & 122 & 0 & 0 & 0 \\
\hline & & & Erkek & Kadın & Toplam & Erkek & Kadin & Toplam \\
\hline \multicolumn{3}{|c|}{ 18-Kayıtlı medyanın basılması ve çoğaltılması } & 833 & 62 & 895 & 3 & 0 & 3 \\
\hline \multirow{6}{*}{$\begin{array}{l}\text { 18-Kayıtlı } \\
\text { medyanın } \\
\text { basılması ve } \\
\text { çoğaltılması }\end{array}$} & \multirow{5}{*}{$\begin{array}{l}\text { 1-Basım ve } \\
\text { basım ile ilgili } \\
\text { hizmet } \\
\text { faaliyetleri }\end{array}$} & 1-Gazetelerin basımı & 164 & 5 & 169 & 1 & 0 & 1 \\
\hline & & 2-Diğer matbaacılik & 568 & 45 & 613 & 2 & 0 & 2 \\
\hline & & $\begin{array}{l}\text { 3-Basım ve yayım öncesi } \\
\text { hizmetler }\end{array}$ & 71 & 3 & 74 & 0 & 0 & 0 \\
\hline & & 4-Ciltçilik ve ilgili hizmetler & 29 & 9 & 38 & 0 & 0 & 0 \\
\hline & & $\begin{array}{l}\text { 5-Diğer baskı ve hakkaklık } \\
\text { işleri (tabaklar ve diğer eşya } \\
\text { üzerine baskı. hakkaklık ve } \\
\text { işleme yapılması gibi) }\end{array}$ & 0 & 0 & 0 & 0 & 0 & 0 \\
\hline & $\begin{array}{l}\text { 2-Kayıtlı } \\
\text { medyanın } \\
\text { çoğaltılması }\end{array}$ & $\begin{array}{l}\text { 0-Kayıtlı medyanın } \\
\text { çoğaltılması (ses. görüntü ve } \\
\text { bilgisayar kaydı) }\end{array}$ & 1 & 0 & 1 & 0 & 0 & 0 \\
\hline
\end{tabular}

Kaynak: SGK İstatistik Yillıkları, 2007-2016, htttps://tuisag.com/yillik-is-kazalari-istatistikleril (Erişim Tarihi:05.04.2019)

Meslek hastalıkları sayısının bu kadar az sayıda olmasının diğer bir sebebi de yükümlülük süresinin fazla olmasıdır. Yükümlülük süresi sigortalının meslek hastalığına sebep olan işinden fiilen ayrıldığı tarih ile meslek hastalığının meydana çıktığı tarih arasında geçen en uzun süreyi ifade eder (T.C. Çalışma ve Sosyal Güvenlik Bakanlığı,İş Sağlığı ve Güvenliği Genel Müdürlüğü, 2019) 
Tablo 3'de yer alan NACE Kodu; Avrupa Topluluğunda Ekonomik Faaliyetlerin İstatistiki Sinıflaması NACE olarak adlandırılmakta olup, Avrupa'da ekonomik faaliyetlerle ilgili istatistiklerin üretilmesi ve yayılması amacına yönelik bir başvuru kaynağı olarak kullanılmaktadır. NACE kodlamasında faaliyet konularına göre işyerlerine/işletmelere altı haneli bir kod verilmektedir. Avrupa Birliği'ne uyum sürecinde ülkemizde de kullanılmaya başlayan bu kodlama sistemini kapsayan düzenlemeler 6331 sayılı İş Sağlığ1 ve Güvenliği Kanunu uyarınca yayınlanmış olup: İşkolları Yönetmeliği (19.12.2012), ekinde 6lı NACE kodları sınıflandırması faaliyet alanına göre ifade edilmiş, İş Sağlığı ve Güvenliğine İlişkin İşyeri Tehlike Sınıfları Tebliği (26.12.2012) ekinde (İşyeri Tehlike Sınıfları Listesi) ise altılı NACE kodu ile sınıflandırılmış işkoluna ait tehlike sınıfları belirtilmiştir. Burada ilk iki rakam ana sinıflandırma numarasını belirtirken, son 4 rakam ise alt sinıflandirmayı ifade etmektedir. Örneğin; 17 başlangıç kodu "Kağıt ve kağıt ürünlerinin imalatı" iken, 17.12 "Kağıt ve mukavva imalatı", 17.12.07 ise "Kağıt ve mukavva imalatı (daha ileri sanayi işlemleri için rulo veya tabaka halinde) (ziftli, lamine, kaplanmış ve emprenye edilmiş olanlar ile krepon ve kırışık kağıtlar dahil)" olarak ifade edilmiş olup, tehlike sınıfı olarak da

“Tehlikeli" şeklinde tanımlanmıştır.

Tablo 3: Basım Sanayi ve Matbaa Sektöründe İşyeri Tehlike Sınıfı Dağılımı

\begin{tabular}{|c|c|c|}
\hline \multicolumn{3}{|c|}{ (Değişik:RG-18/4/2014-28976) } \\
\hline \multicolumn{3}{|c|}{ İŞYERI TEHLİKE SINIFLARI LİSTESİ } \\
\hline $\begin{array}{l}\text { NACE Rev.2 } \\
\text { Altıli Kod }\end{array}$ & NACE Rev.2_Altılı Tanım & $\begin{array}{l}\text { Tehlike } \\
\text { Sinıfi }\end{array}$ \\
\hline 17 & Kağıt ve kağıt ürünlerinin imalatı & \\
\hline 17.1 & Kağıt hamuru, kağıt ve mukavva imalatı & \\
\hline 17.11 & Kağıt hamuru imalatı & \\
\hline 17.11 .08 & Kağıt hamuru imalatı & Tehlikeli \\
\hline 17.12 & Kağıt ve mukavva imalatı & \\
\hline 17.12 .07 & $\begin{array}{l}\text { Kağıt ve mukavva imalatı (daha ileri sanayi işlemleri için rulo veya tabaka } \\
\text { halinde) (ziftli, lamine, kaplanmış ve emprenye edilmiş olanlar ile krepon ve } \\
\text { kırışık kağıtlar dahil) }\end{array}$ & Tehlikeli \\
\hline 17.2 & Kağıt ve mukavva ürünleri imalatı & \\
\hline 17.21 & $\begin{array}{l}\text { Oluklu kağıt ve mukavva imalatı ile kağıt ve mukavvadan yapılan } \\
\text { muhafazaların imalatı }\end{array}$ & \\
\hline 17.21.10 & $\begin{array}{l}\text { Bürolarda, dükkanlarda ve benzeri yerlerde kullanılan kağıt evrak tasnif kutuları, } \\
\text { mektup kutuları ve benzeri eşyaların imalatı }\end{array}$ & Tehlikeli \\
\hline 17.21.11 & Kağıt ve kartondan torba ve çanta imalatı (kese kağıdı dahil) & Tehlikeli \\
\hline 17.21 .12 & Kağıt veya mukavvadan koli, kutu ve benzeri muhafazaların imalatı & Tehlikeli \\
\hline 17.21 .13 & Oluklu kağıt ve oluklu mukavva imalatı (rulo veya tabaka halinde) & Tehlikeli \\
\hline 17.22 & Kağıttan yapılan ev eşyası, sıhhi malzemeler ve tuvalet malzemeleri imalatı & \\
\hline 17.22 .02 & $\begin{array}{l}\text { Kullanıma hazır tuvalet kağıdı, kağıt mendil, temizlik veya yüz temizleme için } \\
\text { kağıt mendil ve havlular ile masa örtüsü ve peçetelerin imalatı (kağıt } \\
\text { hamurundan, kağıttan, selüloz vatkadan veya selüloz lifli ağlardan yapılmış) }\end{array}$ & Tehlikeli \\
\hline 17.22 .03 & $\begin{array}{l}\text { Kağıt veya mukavvadan yapılmış tepsi, tabak, kase, bardak ve benzerlerinin } \\
\text { imalatı }\end{array}$ & Tehlikeli \\
\hline 17.22 .04 & $\begin{array}{l}\text { Hijyenik havlu ve tamponlar, kadın bağı, pedler, bebek bezleri vb. hijyenik } \\
\text { ürünler ile giyim eşyası ve giysi aksesuarlarının imalatı (kağıt hamurundan, } \\
\text { kağıttan, selüloz vatkadan veya selüloz lifli ağlardan yapılmış) }\end{array}$ & Tehlikeli \\
\hline 17.23 & Kağıt kırtasiye ürünleri imalatı & \\
\hline
\end{tabular}




\begin{tabular}{|c|c|c|}
\hline 17.23.04 & $\begin{array}{l}\text { Kullanıma hazır karbon kağıdı, kendinden kopyalı kağıt ve diğer kopyalama veya } \\
\text { transfer kağıtları, mumlu teksir kağıdı, kağıttan ofset tabakalar ile tutkallı veya } \\
\text { yapışkanlı kağıtların imalatı }\end{array}$ & Tehlikeli \\
\hline 17.23.06 & $\begin{array}{l}\text { Kağıt veya mukavvadan ana niteliği bilgi içermeyen eğitim ve ticari kırtasiye } \\
\text { malzemeleri imalatı (ajandalar, defterler, sicil defterleri, muhasebe defterleri, } \\
\text { ciltler, kayıt formları ve diğer benzeri kırtasiye ürünleri) }\end{array}$ & Tehlikeli \\
\hline 17.23 .07 & Kağıt veya mukavvadan dosya, portföy dosya, klasör ve benzerlerinin imalatı & Tehlikeli \\
\hline 17.23 .08 & $\begin{array}{l}\text { Kullanıma hazır basım ve yazım kağıdı ile diğer kağıt ve mukavvaların imalatı } \\
\text { (basılı olanlar hariç) }\end{array}$ & Tehlikeli \\
\hline 17.23 .09 & Baskısız zarf, mektup kartı, yazışma kartı ve benzerlerinin imalatı & Tehlikeli \\
\hline 17.29 & Kağıt ve mukavvadan diğer ürünlerin imalatı & \\
\hline 17.29 .01 & Kağıt veya mukavvadan etiketlerin imalatı & Tehlikeli \\
\hline 17.29.02 & $\begin{array}{l}\text { Filtre kağıdı, kartonları ve mukavvaları, kağıt hamurundan filtre edici blok ve } \\
\text { levhalar ile kalıplanmış ya da sıkıştırılmış eşyaların imalatı (kağıt veya karton } \\
\text { esaslı contalar ve rondelalar dahil) }\end{array}$ & Tehlikeli \\
\hline 17.29 .03 & $\begin{array}{l}\text { Sigara kağıdı, kağıt ve mukavvadan bobin, makara, masura, yumurta viyolü ve } \\
\text { benzeri kağıt, mukavva veya kağıt hamurundan destekler ile kağıttan hediyelik ve } \\
\text { süs eşyaları imalatı }\end{array}$ & Tehlikeli \\
\hline 17.29.04 & $\begin{array}{l}\text { Jakar makinelerinde kullanmak için kağıt ve mukavvadan kartlar ile kaydedici } \\
\text { cihazlara mahsus diyagram kağıtları imalatı (bobin, tabaka/disk halinde) }\end{array}$ & Tehlikeli \\
\hline 18 & Kayıtlı medyanın basılması ve çoğaltılması & \\
\hline 18.1 & Basım ve basım ile ilgili hizmet faaliyetleri & \\
\hline 18.11 & Gazetelerin basımı & \\
\hline 18.11.01 & $\begin{array}{l}\text { Gazetelerin, dergilerin ve süreli yayınların basım hizmetleri (haftada dört veya } \\
\text { daha fazla yayınlananlar) }\end{array}$ & Tehlikeli \\
\hline 18.12 & Diğer matbaacilık & \\
\hline 18.12.01 & $\begin{array}{l}\text { Çıkartma, takvim, ticari katalog, tanıtım broşürü, poster, satış bülteni, kartpostal, } \\
\text { davetiye ve tebrik kartları, yıllık, rehber, resim, çizim ve boyama kitapları, çizgi } \\
\text { roman vb. basım hizmetleri }\end{array}$ & Tehlikeli \\
\hline 18.12.02 & $\begin{array}{l}\text { Gazetelerin, dergilerin ve süreli yayınların basım hizmetleri (haftada dört kereden } \\
\text { daha az yayınlananlar) }\end{array}$ & Tehlikeli \\
\hline 18.12.03 & $\begin{array}{l}\text { Ansiklopedi, sözlük, kitap, kitapçık, müzik eserleri ve müzik el yazmaları, atlas, } \\
\text { harita vb. basım hizmetleri }\end{array}$ & Tehlikeli \\
\hline 18.12 .04 & Röprodüksiyon basımı (bir sanat eserinin aslını bozmadan basılması) & Tehlikeli \\
\hline 18.12 .05 & Serigrafi faaliyetleri & Tehlikeli \\
\hline 18.12.06 & $\begin{array}{l}\text { Posta pulu, damga pulu, matbu belgeler, tapu senetleri, akıllı kart, çek defterleri, } \\
\text { kağıt para ve diğer değerli kağıtların ve benzerlerinin basım hizmetleri }\end{array}$ & Tehlikeli \\
\hline 18.12 .07 & Plastik, cam, metal, ağaç ve seramik üstüne baskı hizmetleri & Tehlikeli \\
\hline 18.13 & Basım ve yayım öncesi hizmetler & \\
\hline 18.13.01 & $\begin{array}{l}\text { Basımda kullanmak üzere baskı klişeleri ya da silindirleri ile diğer basım } \\
\text { unsurlarının üretilmesi (klişecilik vb.) ile mizanpaj, dizgi, tabaka yapım } \\
\text { hizmetleri, gravür baskı için silindirlerin kazınması veya asitle aşındırılması vb. } \\
\text { hizmetler }\end{array}$ & $\begin{array}{l}\text { Çok } \\
\text { Tehlikeli }\end{array}$ \\
\hline 18.13.02 & $\begin{array}{l}\text { Basım öncesi bilgisayar destekli hizmetler (bilgisayar destekli sayfa tasarımı ile } \\
\text { saydam, asetat, reprografik sunum araçları ve diğer sayısal sunum ortamları, } \\
\text { taslaklar, planlar vb. baskı ürünlerinin tasarlanması) (masa üstü yayımcılık dahil) }\end{array}$ & Az Tehlikel \\
\hline 18.14 & Ciltçilik ve ilgili hizmetler & \\
\hline 18.14.01 & $\begin{array}{l}\text { Ciltçilik ve ilgili hizmetler/mücellitlik (katlama, birleştirme, dikme, yapıştırma, } \\
\text { kesme, kapak takma gibi işlemler ile damgalama, Braille alfabesi kopyalama vb. } \\
\text { hizmetler) }\end{array}$ & Tehlikeli \\
\hline 18.2 & Kayıtlı medyanın çoğaltılması & \\
\hline 18.20 & Kayıtlı medyanın çoğaltılması & \\
\hline
\end{tabular}




\begin{tabular}{|c|c|c|}
\hline 18.20 .02 & $\begin{array}{l}\text { Ses ve görüntü kayıtlarının çoğaltılması hizmetleri (CD'lerin, DVD'lerin, kasetlerin } \\
\text { ve benzerlerinin asıl (master) kopyalarından çoğaltılması) }\end{array}$ & Az Tehlikeli \\
\hline 18.20 .03 & $\begin{array}{l}\text { Yazılımların çoğaltılması hizmetleri (CD, kaset vb. ortamlardaki bilgisayar } \\
\text { yazılımlarının ve verilerin asıl (master) kopyalarından çoğaltılması) }\end{array}$ & Az Tehlikeli \\
\hline 20 & Kimyasalların ve kimyasal ürünlerin imalatı & \\
\hline 20.3 & $\begin{array}{l}\text { Boya, vernik ve benzeri kaplayıcı maddeler ile matbaa mürekkebi ve macun } \\
\text { imalatı }\end{array}$ & \\
\hline 20.30 & $\begin{array}{l}\text { Boya, vernik ve benzeri kaplayıcı maddeler ile matbaa mürekkebi ve macun } \\
\text { imalatı }\end{array}$ & \\
\hline 20.30 .13 & $\begin{array}{l}\text { Diğer boya, vernik ve ilgili ürünlerin imalatı (renk ayarlayıcılar, matbaa } \\
\text { mürekkepleri, solventler, incelticiler (tiner)) }\end{array}$ & $\begin{array}{l}\text { Çok } \\
\text { Tehlikeli }\end{array}$ \\
\hline 20.5 & Diğer kimyasal ürünlerin imalatı & \\
\hline 20.59 & Başka yerde sınıflandırılmamış diğer kimyasal ürünlerin imalatı & \\
\hline 20.59 .01 & $\begin{array}{l}\text { Fotografik levha ve filmlerin (hassaslaştırılmış, ışığa maruz kalmamış olanlar), } \\
\text { anında baskılanan filmlerin, fotoğrafçılıkta kullanılan kimyasal müstahzarların ve } \\
\text { karışımsız (saf) ürünlerin imalatı }\end{array}$ & $\begin{array}{l}\text { Çok } \\
\text { Tehlikeli }\end{array}$ \\
\hline 28 & Başka yerde sınıflandırılmamış makine ve ekipman imalatı & \\
\hline 28.99 & Başka yerde sınıflandırılmamış diğer özel amaçlı makinelerin imalatı & \\
\hline 28.99 .01 & $\begin{array}{l}\text { Basım ve ciltleme makineleri ile basıma yardımcı makinelerin ve bunların } \\
\text { parçalarının imalatı (ofset baskı makinesi, tipografik baskı makinesi, dizgi } \\
\text { makinesi, baskı kalıpları için makineler, ciltleme makinesi vb.) (büro tipi baskı } \\
\text { makinesi hariç) }\end{array}$ & Tehlikeli \\
\hline 32 & Diğer imalatlar & \\
\hline 32.99 & Başka yerde sınıflandırılmamış diğer imalatlar & \\
\hline 32.99 .08 & $\begin{array}{l}\text { Tarih verme, damga, mühür veya numara verme kaşeleri, numeratör, elle çalışan } \\
\text { basım aletleri, kabartma etiketleri, el baskı setleri, hazır daktilo şeritleri ve } \\
\text { ıstampaların imalatı }\end{array}$ & Az Tehlikeli \\
\hline 46 & Toptan ticaret (Motorlu kara taşıtları ve motosikletler hariç) & \\
\hline 46.73 & Ağaç, inşaat malzemesi ve sıhhi teçhizat toptan ticareti & \\
\hline 46.73 .02 & Boya, vernik ve lak toptan ticareti & Tehlikeli \\
\hline
\end{tabular}

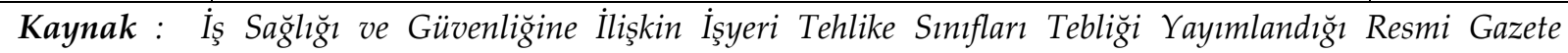
Tarihi/Sayısı: 26.12.2012 (Değ.20.02.2016/29630), Ek-Tehlike Sınfları Listesi (NACE Kodları 20.02.2016), Basım Sanayi ve Matbaa Sektörü İle Ilgili Bölümleri http://www.mevzuat.gov.tr/Metin.Aspx?MevzuatKod=9.5.16909EMevzuatIliski=0EsourceXmlSearch= (Erişim Tarihi:09.04.2019)

Tablo 3'deki 26.12. 2012 tarihli İş Sağlığı ve Güvenliğine İlişkin İş yeri Tehlike Sınıfları Tebliğinin Ek-Tehlike Sınıfları Listesi'inde yer alan iş yerlerinin tablodaki dağılımı basım sanayi ve matbaa sektörünün baskı öncesi, baskı ve baskı sonrası olmak üzere üç kısımdan oluşması nedeniyle iş yerlerinin tehlike sınıfı dağılımını da değiştirmektedir. Tablo 3 incelendiğinde çoğunlukla tehlike sınıfı grubu ağırlıktadır ama gelişen teknolojiyi basım sanayi ve matbaa sektörü de yakından takip etmektedir bu yüzden çok tehlikeli iş sahaları tehlikeli ve az tehlikeli sahalara düşürülmektedir. SGK istatistiklerinde de iş kazaları ve meslek hastalıkları verileri çoğunluklu iş kolu kayıtlı medyanın basılması ve çoğaltılması bölümü adı altında toplanmaktadır. Tablo 1'de tüm sektörlerle karşılaştırıldığında düşük olmasının diğer bir sebebi de basım sanayi ve matbaa sektörünün bu üç kısımdan oluşması iş sahasındaki tehlike boyutunu düşürmektedir. 


\section{Sonuç ve Öneriler}

Basım sanayi ve matbaa sektöründe genel olarak aşağıdaki önlemler alınmalıdır:

- Ağır parçalar kaldırılıp taşınırken insan gücü yerine palanga ve diğer kaldırıcı ekipmanlarla taşıma araçlarından da yararlanmak gerekmektedir. Ayrıca ayakları korumak için çelik uçlu ayakkabılar kullanılmalıdır.

- Kağıt kesme sırasında, giyotin makinalarının kullanımında gerekli eğitimi almayan operatörlere kesinlikle giyotin makineleri kullandırılmamalıdır.

- Kimyasallarla ilgili gerekli kişisel koruyu donanım kullandırılmalıdır.

- Kullanılan kimyasallar için Güvenlik Bilgi Formu hazırlanmalı, bilgileri iş ortamında bulunmalı ve güvenlik önlemleri hakkında çalışanlar bilgilendirilmelidir.

- Tozlar için, toz ölçümleri yaptırılarak gerekli ise o birimde veya bölümde çalışan personellere kişisel koruyucu malzemeler kullandırılmalıdır. Tozun çalışma ortamındaki yoğunluğunun azaltılmasıyla ilgili teknik çalışmalar yapılmalıdır. Kullanılan çalışma yöntemi ve işçilerin fiziki faaliyetleri göz önünde bulundurularak gerekli havalandırmaların devamlı surette yapılması gerekmektedir.

- Gürültünün kontrol altına alınabilmesi için;

- Gürültünün kaynağında azaltılması

- Gürültünün alıcıya ulaşmadan engellenmesi

- Kişisel koruyucu kullanılması

- Maruziyet süresinin azaltılması

- Makine ve koruyucu donanımlarında CE işaretinin bulunması gerekli, bize ürün kalitesi hakkında bilgi vermesi açısından, CE işareti ürünün Avrupa Birliği Normlarına uygun olduğunu belirtmektedir.

- Çalışma araç ve gereçlerinin insanın gövde yapısına uygun düşecek biçimde düzenlenmesi elverişli 1şık ses, havalandırma, 1sı, nem gibi çalışma koşullarının sağlanması gibi ergonomi unsurlarına dikkat edildiğinde iskelet sistemi rahatsızlıkları büyük ölçüde önlenebilmektedir. Matbaalarda ağırlık kaldırma, indirme ve yük taşıma gibi konularda vücuda doğru ve güvenli kullanma eğitimleri verilmesi gerekmektedir. Uygun ergonomik koşullar sağlandığ 1 takdirde hem işçilerin sağlığı konusunda önemli bir adım atılmış olacak, hem de hastalıktan doğan sağlık harcamaları, tazminatlar ve iş günü kayıpları önlenmiş olacaktır.

- Psikolojik stres ve aşırı yüklenmeler için stres azaltıcı yöntemlerin uygulanması, çalışanın tatmini ve üretimin artışına katkıda bulunacağı gibi sağlık harcamalarında da azalmaya neden olacaktır.

- Termal konfor ölçümleri mevsim koşulları değişiminde periyodik olarak yapilmalidir.

- Periyodik olarak aydınlatma ölçümleri yapılmalıdır.

- Sarı çizgi ile yürüme alanı, malzeme alanı, makine alanları belirlenmelidir.

- Malzemelerin düşmesine karşı düzenli istiflenmelidir.

- Geçitlere malzeme konulmamalı, depo bölümündeki geçitlere konulan malzeme kaldırılmalıdır.

- Atıklar ve çevreye zararları hakkında işçilere bilgilendirme eğitimleri yapılmalıdır. 
- Yangın tüplerinin yetkili teknik elemanlar tarafından 6 ayda bir kontrolleri yapılmalıdır. Yangın tatbikatı yapılmalı ve en az yılda 2 kez yangin tatbikatı tekrarlanmalıdır. Yangın söndürme ekipmanının önü kapatılmamalı. Duman algılama sisteminin çalışırlığı kontrol edilmelidir.

Basım sanayi ve matbaa sektöründe de yaşanan iş kazaları ve meslek hastalıklarının önlenmesi, en aza indirilmesi için şuanda iş sağlığı ve güvenliğinde benimsenmeye çalışılan proaktif (önleyici) yaklaşımla yaklaşılmalı, belirlenmeli, planlamada ve uygulamada bilgiler sürekli olarak güncellenmelidir. Bunun gerçekleşmesi de, düzgün kayıt ve bildirim sisteminin sağlanmasına bağlıdır. Böyle bir sistemin kurulmasında, iş yerlerinde sağlık ve güvenlik birimlerinin kurulması başta olmak üzere, işçi, işveren, üniversiteler ve devlet kurumlarına da görevler düşmekte ve bu konuda iş birliği yapılmalıdır.

\section{Kaynakça}

bilgit.com. (2019, 04 09). Risk Değerlendirme Kontrol Listeleri. Basım Sanayii ve Matbaalar için Kontrol Listesi: https://www.bilgit.com/kontrol-listeleri.html adresinden alındı

Erdim, H., Türkman, A., \& Atalar, C. (2010). Matbaalarda Iş̧ Sağhlğı ve Güvenliği El Kitabı.

Fişek, A., \& Taşyürek, M. (2019, 04 09). Matbaacıllk İşkolunda İş Sağlığı Güvenliği. www.isguvenligi.net: https://www.isguvenligi.net/iskollari-ve-is-guvenligi/matbaacilik-iskolunda-is-sagligi-veguvenligi/ adresinden alınd

İzmir Alternatif OSGB. (2019, 04 09). Matbaalarda İş Sağlı̆̆ı ve Güvenliği - Kimyasallar. İzmir Alternatif OSGB:http://www.izmiralternatif.com.tr/haberdetay/matbaalarda-sagligi-ve-guvenligikimyasallar/ adresinden alındı

Marmara Üniversitesi. (2019, 04 09). Matbaacılık Mesleği Hakkında. Marmara Üniversitesi, Teknik Eğitim Fakültesi, Matbaa Eğitimi: http://mtb.tef.marmara.edu.tr/genel-bilgiler/matbaacilikmeslegi-hakkinda/ adresinden alındı

Matbaa Bilgi Kütüphanesi. (2019, 04 09). Modern Matbaacılıkta İş Akışı. Matbaa Bilgi Kütüphanesi: https://matbaabilgi.wordpress.com/2010/06/24/modern-matbaacilikta-is-akisi/ adresinden alındı

Mevzuat Bilgi Sistemi. (2019, 04 09). Çalışanların İş Să̆ğı̆̆ ve Güvenliği Eğitimlerinin Usul ve Esaslar Hakkında Yönetmelik Resmî Gazete Tarihi: 15.05.2013 Resmî Gazete Sayısı: 28648. mevzuat.gov.tr: http://www.mevzuat.gov.tr/Metin.Aspx?MevzuatKod=7.5.18371\&MevzuatIliski=0\&sourceXm 1Search $=$ adresinden alınd 1

Mevzuat Bilgi Sistemi. (2019, 04 09). İş Sağlı̆̆ı ve Güvenliği Risk Değerlendirmesi Yönetmeliği, Resmî Gazete Tarihi: 29.12.2012, Resmî Gazete Saylsi: 28512. mevzuat.gov.tr: http://www.mevzuat.gov.tr/Metin.Aspx?MevzuatKod=7.5.16925\&MevzuatIliski=0\&sourceXm 1Search $=$ adresinden alınd 1

Mevzuat Bilgi Sistemi. (2019, 04 09). İş Sağhlğı ve Güvenliğine İlişkin İşyeri Tehlike Sınıfları Tebliği, Resmî Gazete Tarihi: 26.12.2012 Resmî Gazete Sayısl: 28509 EK-1 İşyeri Tehlike Sinıfları Listesi, . mevzuat.gov.tr:

http://www.mevzuat.gov.tr/Metin.Aspx?MevzuatKod=9.5.16909\&MevzuatIliski=0\&sourceXm 1Search $=$ adresinden alınd 1

Mevzuat Bilgi Sistemi. (2019, 04 09). İşyerlerinde Acil Durumlar Hakkında Yönetmelik, Resmî Gazete Tarihi: 18.06.2013, Resmî Gazete Sayısi: 28681. mevzuat.gov.tr: 
http://www.mevzuat.gov.tr/Metin.Aspx?MevzuatKod=7.5.18493\&MevzuatIliski=0\&sourceXm 1Search $=$ adresinden alınd 1

Mevzuat Bilgi Sistemi. (2019, 04 09). Kimyasal Maddelerle Çalışmalarda Să̆lık ve Güvenlik Önlemleri Hakkında Yönetmelik, Resmî Gazete Tarihi: 12.08.2013, Resmî Gazete Sayısi: 28733. mevzuat.gov.tr:

http://www.mevzuat.gov.tr/Metin.Aspx?MevzuatKod=7.5.18709\&MevzuatIliski=0\&sourceXm 1Search $=$ adresinden alınd 1

Mevzuat Bilgi Sistemi. (2019, 04 09). Kişisel Koruyucu Donanımların İsyerlerinde Kullanılması Hakkında Yönetmelik, Resmî Gazete Tarihi: 02.07.2013, Resmî Gazete Sayısı: 28695. mevzuat.gov.tr: http://www.mevzuat.gov.tr/Metin.Aspx?MevzuatKod=7.5.18540\&MevzuatIliski=0\&sourceXm 1Search $=$ adresinden alınd 1

Mevzuat Bilgi Sistemi. (2019, 04 09). Sağllk ve Güvenlik Isşaretleri Yönetmeliği, Resmî Gazete Tarihi: 11.09.2013, Resmî Gazete Sayısi: 28762. mevzuat.gov.tr: http://www.mevzuat.gov.tr/Metin.Aspx?MevzuatKod=7.5.18829\&MevzuatIliski=0\&sourceXm lSearch $=$ adresinden alınd 1

T.C. Cumhurbaşkanlığ1 Resmi Gazete, 6331 İş Sağllğ 1 ve Güvenliği Kanunu. (2019, 04 09). 6331 İş Sağhlğı ve Güvenliği Kanunu, 30 Haziran 2012 tarihli Resmî Gazete 28339 sayll . mevzuat.gov.tr: http://www.mevzuat.gov.tr/MevzuatMetin/1.5.6331.pdf adresinden alınd1

T.C. Çalışma ve Sosyal Güvenlik Bakanlığ1, İs Sağlığı ve Güvenliği Genel Müdürlüğü. (2019, 0409$)$. Ulusal İş Sağhlğı ve Güvenliği Politika Belgesi - III ve Eylem Planı 2014-2018. www.aybu.edu.tr: https://www.aybu.edu.tr/isg/contents/files/ulusal_isgPolitikaBelgesi.pdf adresinden alındı

T.C. Resmî Gazete, 5510 Sosyal Sigortalar ve Genel Sağlık Sigortası Kanunu,. (2019, 04 09). 5510 Sosyal Sigortalar ve Genel Sağlık Sigortası Kanunu, Kabul Tarihi:31.05.2006, Yayımlandı̆̆̆ Resmî Gazete : Tarih: 16/6/2006. mevzuat.gov.tr: www.mevzuat.gov.tr/MevzuatMetin/1.5.5510.doc adresinden alındı 
AJIT-e: Online Academic Journal of Information Technology

2019 Bahar/Spring-Cilt/Vol: 10 - Sayı/Num: 37

DOI: 10.5824/1309-1581.2019.2.004.x 